Apren Holomoan Hutasoit, Sugianta Ovinus Ginting, Eric

\title{
Kualitas Layanan, Promosi, Citra Perusahaan Terhadap Kepuasan Nasabah PT Bank BTPN Tbk Cabang Medan
}

\author{
Apren Halomoan Hutasoit \\ STIE Mikroskil \\ Sugianta Ovinus Ginting \\ STIE Mikroskil \\ Eric \\ STIE Mikroskil
}

apren.halomoan@mikroskil.ac.id

\begin{abstract}
Abstrak
Persaingan perbankan dalam mendapatkan nasabah tentu tidak lepas dari kenyamanan nasabah dalam melakukan transaksi perbankan. Kenyamanan nasabah akan menjadi hal utama yang akan membentuk keinginan calon nasabah untuk menjadi nasabah yang tetap melakukan transaksi. Penelitian ini bertujuan untuk mengetahui dan menganalisis pengaruh kualitas layanan, promosi dan citra perusahaan terhadap kepuasan nasabah PT Bank BTPN Tbk Cabang Medan, baik secara simultan maupun parsial. Jenis penelitian yang digunakan dalam penelitian ini adalah penelitian kuantitatif. Populasi pada penelitian ini adalah nasabah Bank BTPN yang sudah bergabung pada Bank BTPN selama 2 tahun pada periode Januari 2017- Desember 2019 berjumlah 559 orang. Teknik pengambilan sampel menggunakan metode non probability sampling dengan jumlah sampel sebanyak 233 orang. Teknik analisis data yang digunakan untuk menjawab hipotesis adalah analisis regresi linear berganda. Berdasarkan hasil penelitian menunjukkan bahwa kualitas layanan secara parsial tidak berpengaruh signifikan terhadap kepuasan nasabah. Promosi secara parsial tidak berpengaruh signifikan terhadap kepuasan nasabah. Citra perusahaan secara parsial tidak pengaruh signifikan terhadap kepuasan nasabah. Kualitas layanan, promosi dan citra perusahaan secara simultan berpengaruh terhadap kepuasan nasabah.
\end{abstract}

Kata Kunci: Kualitas Layanan, Promosi, Citra Perusahaan, Kepuasan Nasabah

\section{Pendahuluan}

Persaingan perbankan dalam mendapatkan nasabah tentu tidak lepas dari kenyamanan nasabah dalam melakukan transaksi perbankan. Kenyamanan nasabah akan menjadi hal utama yang akan membentuk keinginan calon nasabah untuk menjadi nasabah yang tetap melakukan transaksi. Peran bank di dalam perekonomian sangat penting dalam mendukung proses pengeluaran dan pemasukan dana dari masyarakat. Bank juga memiliki peran sentral di dalam mendukung kemajuan ekonomi di Indonesia.

Dalam dunia perbankan kepuasan sangat diperlukan untuk meningkatkan dana bank. Kepuasan merupakan tingkat perasaaan dimana seseorang menyatakan hasil perbandingan atas kinerja produk jasa yang diterima dengan yang diharapkan. Dengan terciptanya kepuasan nasabah dapat memberikan beberapa manfaat, diantaranya hubungan antara bank dan nasabahnya menjadi harmonis, memberikan dasar yang baik bagi nasabah membeli produk lain di bank yang sama dan terciptanya loyalitas nasabah dan membentuk suatu rekomendasi dari mulut ke mulut yang menguntungkan bagi bank. Apabila nasabah tidak puas maka nasabah akan beralih ke bank lain. 
Faktor yang mampu memberikan kepuasan kepada nasabah adalah kualitas layanan, promosi dan citra perusahaan. Kualitas layanan merupakan suatu kondisi dinamis yang berhubungan dengan produk, jasa, manusia, proses dan lingkungan yang memenuhi atau melebihi harapan (Susilo, 2012). Kualitas layanan dalam hal ini berupa kemudahan, kecepatan, hubungan, kemampuan dan keramahtamahan yang ditujukan melalui sikap dan sifat dalam memberikan layanan untuk kepuasan nasabah. Nasabah yang merasa puas dengan kualitas layanan cenderung lebih memilih memakai jasa dari perbankan tersebut serta akan memberikan rekomendasi kepada orang lain untuk membeli di tempat yang sama dan sebaliknya apabila nasabah merasa tidak puas dengan kualitas layanan maka nasabah akan beralih ke bank lain.

Faktor lainnya yang mempengaruhi kepuasan nasabah adalah promosi. Promosi merupakan sarana yang baik untuk menarik dan mempertahankan nasabahnya (Sopiah, 2013). Promosi yang digunakan perbankan adalah iklan melibatkan media cetak maupun media elektronik yang dapat mengirimkan pesan kepada sejumlah kelompok individu pada saat bersamaan. Idealnya promosi harus mampu menarik perhatian, mempertahankan ketertarikan, membangkitkan keinginan, dan menggerakan tindakan. Perusahaan menggunakan promosi untuk dapat memperkenalkan produk, menginformasikan keunggulan produk dan menciptakan kesadaran tertinggi bagi nasabah agar produk dapat menjadi salah satu pilihan nasabah.

Selain promosi yang dapat menjadi pertimbangan dalam melakukan kepuasan nasabah faktor lainya adalah citra perusahaan. Citra perusahaan merupakan kesan, perasaan dan gambaran dari publik terhadap perusahaan, kesan yang sengaja diciptakan dari suatu objek, orang-orang atau organisasi (Lupiyoadi, 2013). Bank tersebut telah memiliki citra perusahaan yang positif di mata nasabah. Oleh karena itu, citra perusahaan merupakan hal yang terpenting dalam tiap layanan. Hal tersebut dapat berdampak pada persepsi kualitas layanan. Jika bank memiliki citra yang baik di mata nasabah, maka kesalahan-kesalahan kecil dapat dimaafkan oleh nasabah. Apabila kesalahan tersebut terjadi berulang kali maka citra perusahaan dapat rusak.

Citra perusahaan merupakan suatu gambaran mengenai baik atau buruknya suatu perusahaan. Gambaran baiknya perusahaan pada persepsi nasabah akan memberikan dampak yang positif terhadap peningkatan kepuasan nasabah (Mulyaningsih and Suasana, 2016). Bank yang baik dan menjalankan fungsinya dengan baik maka akan mendapatkan kepercayan bagi nasabah yang menabung, kepercayaam tersebut harus dijaga dan memberikan kesan yang baik kepada nasabah (Wijayanto, 2015).

Dari hasil prasurvey yang dilakukan, bahwa dalam dua tahun berturut terlihat jumlah nasabah dalam setiap bulannya tidak menunjukkan adanya peningkatan. Beberapa nasabah yang menabung dibank memberikan pernyataan bahwa Bank BTN telah menunjukkan citra yang positif dan memperoleh kepercayaan. Dengan mendapatkan kepercayaan seharusnya ada penambahan jumlah nasabah pada setiap bulannya. Oleh karena itu, peneliti tertarik untuk melakukan penelitian ini dengan mengangkat variabel kualitas pelayanan, promosi dan citra perusahaan sebagai variabel yang akan diteliti.

\section{Landasan Teori dan Pengembangan Hipotesis}

\section{Kualitas Layanan}

Kualitas layanan adalah seberapa jauh perbedaan antara kenyataan dan harapan nasabah atas layanan yang diterima atau diperoleh (Aksa, 2011) Kualitas layanan yang dipersepsikan nasabah berpengaruh signifikan terhadap kepuasan nasabah (Suryani, 2017). Peneliti menyimpulkan bahwa kualitas pelayanan adalah pelayanan jasa yang diberikan dari perusahaan dalam melayani setiap nasabah yang menggunakan produk yang mereka tawarkan. 
indikator kualitas layanan adalah: reliabilitas (reliability), daya danggap (responsiveness), jaminan (assurance), empati (empathy), bukti fisik (tangible) (Tjiptono, 2014).

\section{Promosi}

Promosi merupakan sarana yang paling ampuh untuk menarik dan mempertahankan nasabahnya (Kasmir, 2010). Promosi merupakan kegiatan yang ditujukan untuk mempengaruhi nasabah agar mereka dapat menjadi kenal akan produk yang ditawarkan oleh perusahaan kepada mereka dan kemudian mereka menjadi senang lalu menabung produk tersebut (Sunyoto, 2014). Peneliti menyimpulkan bahwa promosi merupakan aktivitas pemasaran yang berusaha menyebarkan informasi, mempengaruhi atau membujuk dan mengingatkan pasar sasaran atas perusahaan dan produknya agar bersedia menerima dan loyal pada produk yang ditawarkan perusahaan yang bersangkutan dan sebagai alat untuk meneruskan informasi dalam proses pengambilan keputusan untuk menabung. Indikator promosi adalah: kualitas promosi, kuantitas promosi, waktu promosi dan ketepatan atau kesesuaian sasaran promosi (Kotler, 2013).

\section{Citra Perusahaan}

Citra perusahaan adalah gambaran yang dapat dilihat oleh individu mengenai baik atau buruknya suatu perusahaan. Citra perusahaan dapat memberikan kemampuan pada perusahaan untuk mengubah harga premium, menikmati penerimaan lebih tinggi dibanding pesaing yang membuat kepercayaan pelanggan pada perusahaan (Kotler, 2013). Peneliti menyimpulkan bahwa citra perusahaan merupakan hasil evaluasi dalam diri seseorang berdasarkan pengertian dan pemahaman terhadap rangsangan yang telah diolah, diorganisasikan dan disimpan dalam benak seseorang dengan tujuan untuk mengetahui secara pasti apa yang ada dalam setiap pikiran individu mengenai suatu objek, bagaimana mereka memahaminya dan apa yang mereka sukai atau tidak sukai dari objek tersebut. Indikator citra perusahaan, yaitu: produk umum, atribut, sikap dan kinerja (common product, attributes, benefists or attitudes), karyawan dan layanan (people and relationship), nilai yang dimiliki perusahaan (value and programs), dan identitas perusahaan (corporate credibility) (Kotler, 2013).

\section{Kepuasan Nasabah}

Kepuasan nasabah adalah perasaan senang atau kecewa seseorang yang berasal dari perbanding anantara kesannya terhadap kinerja atau hasil produk dan harapan-harapan lainnya (Tjiptono, 2014). Kepuasan nasabah adalah tingkat kepuasan seseorang dengan membandikan kinerja produk (hasil) yang nasabah rasakan dengan harapannya (Sumarni, 2012). Kepuasan nasabah merupakan tingkat pemenuhan kebutuhan dan keinginan yang nasabah merespon dan rasakan dengan perbandingan dengan harapannya. indikator kepuasan nasabah adalah: kepuasan nasabah keseluruhan, dimensi nasabah, konfirmasi harapan, niat menabung, kesediaan untuk merekomendasi dan ketidakpuasan nasabah (Suasana, 2016). 
INOBIS: Jurnal Inovasi Bisnis dan Manajemen Indonesia

Volume 03, Nomor 04, September 2020

Apren Holomoan Hutasoit, Sugianta Ovinus Ginting, Eric

\section{Kerangka Konseptual dan Hipotesis}

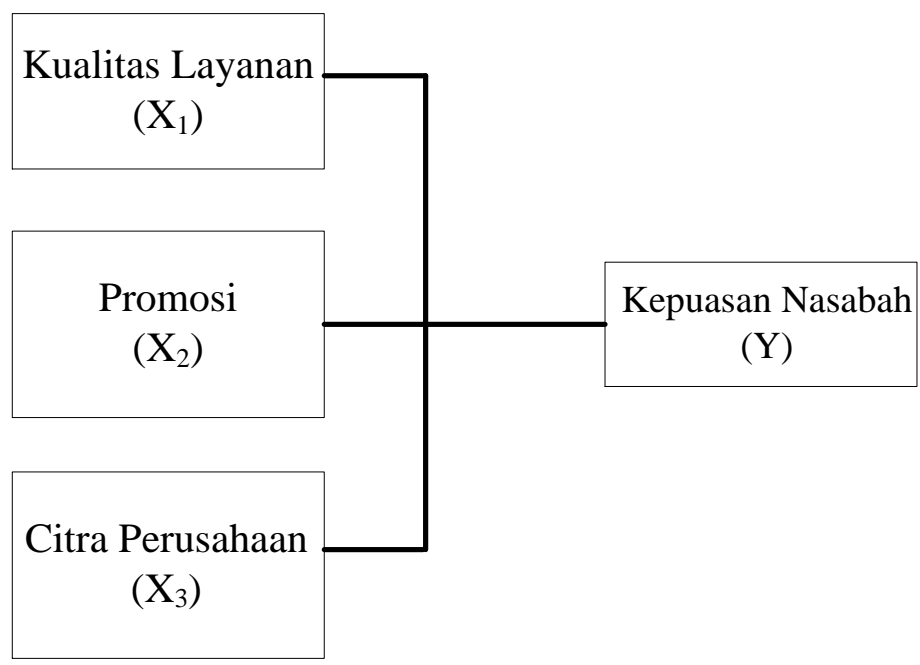

Gambar 1.Kerangka Konseptual

Dari hasil kerangka konseptual yang telah dibangun, maka peneliti merangkum beberapa hipotesis pada penelitian ini, diantaranya adalah:

$\mathrm{H}_{1}$ : Kualitas layanan berpengaruh positif dan signifikan terhadap kepuasan nasabah

$\mathrm{H}_{2}$ : Promosi berpengaruh positif dan signifikan terhadap kepuasan nasabah

$\mathrm{H}_{3}$ : Citra perusahaan berpengaruh positif dan signifikan terhadap kepuasan nasabah

$\mathrm{H}_{4}$ : Kualitas layanan, promosi dan citra perusahaan berpengaruh positif dan signifikan

terhadap kepuasan nasabah

\section{Metode Penelitian}

Penelitian ini menggunakan metode deskriptif kuantitatif. Metode penelitian deksriptif kuantitatif dapat diartikan sebagai metode penelitian yang berlandaskan pada filsafat positivism, digunakan untuk meneliti pada populasi atau sampel tertentu, pengumpulan data menggunakan instrumen penelitian, analisis data bersifat kuantitatif atau statistik, dengan tujuan untuk menguji hipotesis yang telah ditetapkan (Sugiyono, 2014). Objek dalam penelitian ini adalah nasabah pada PT Bank BTPN Cabang Medan dengan populasi berjumlah 559 orang. Teknik pengambilan sampel yang digunakan simple random sampling. Simple random sampling adalah pengambilan anggota sampel dari populasi dilakukan secara acak tanpa memperhatikan strata yang ada dalam populasi itu (Sugiyono, 2014). Dengan demikian jumlah sampel yang akan diteliti adalah 233 orang. Metode pengumpulan data yang digunakan dalam penelitian ini adalah melakukan pembagian kuesioner, observasi, wawancara dan studi kepustakaan. Pengisian kuesioner diukur dengan menggunakan skala likert. Penelitian ini dilakukan pada Maret 2020 hinga Agustus 2020. Untuk menguji hipotesis pada penelitian ini, digunakan alat analisis regresi linear berganda.

\section{Hasil Penelitian}

Sebelum dilakukan pegolahan data, peneliti menguji kualitas data dengan melakukan pengujian validitas dan realibilitas. Pada uji validitas, pernyataan pada penelitian ini valid karena $r_{\text {hitung }}>r_{\text {tabel }}=0,113$ dan nilai sig $0,005>0,000$. Pada uji reliabilitas, pernyataan pada 
penelitian ini reliabel karena nilai Alpha Cronbach pada pernyataan tersebut lebih besar dari 0,60 .

Analisis linear berganda digunakan untuk mengetahui pengaruh kualitas layanan, promosi, dan citra perusahaan terhadap kepuasan nasabah. Hasil analisis regresi linear berganda dapat dilihat dari tabel berikut :

Tabel 1. Hasil Penelitian

\begin{tabular}{|c|c|c|c|c|}
\hline $\begin{array}{c}\text { Uji } \\
\text { Hipotesis }\end{array}$ & Variabel & Sig & Beta & R Square \\
\hline $\begin{array}{c}\text { Uji } \\
\text { Simultan }\end{array}$ & KL,P,CP $\rightarrow$ KP & $\mathbf{0 , 0 4 8}$ & & \\
\hline \multirow{3}{*}{ Uji Parsial } & KL $\rightarrow$ KP & $\mathbf{0 , 3 3 1}$ & $\mathbf{0 , 0 7 3}$ & \\
\cline { 2 - 4 } & $\mathbf{P} \rightarrow$ KP & $\mathbf{0 , 0 7 3}$ & $\mathbf{0 , 1 7 0}$ & \\
\cline { 2 - 4 } & $\mathbf{C P} \rightarrow$ KP & $\mathbf{0 , 2 0 2}$ & $\mathbf{0 , 1 3 0}$ & \\
\hline $\begin{array}{c}\text { Koefisien } \\
\text { Determinasi }\end{array}$ & \multicolumn{2}{|c}{} & $\mathbf{0 , 0 2 1}$ \\
\hline
\end{tabular}

Keterangan:

$\begin{array}{ll}\mathrm{KP} & =\text { Kepuasan Nasabah } \\ \mathrm{KL} & =\text { Kualitas Layanan } \\ \mathrm{P} & =\text { Promosi } \\ \mathrm{CP} & =\text { Citra Perusahan }\end{array}$

Dari Tabel 1 terlihat bahwa dalam hasil uji hipotesis secara simultan menunjukkan variabel KL,P,CP berpengaruh terhadap KP dengan hasil signifikan. Hasil uji hipotesis secara parsial menunjukkan bahwa KL tidak signifikan, P tidak signifikan, dan CP tidak signifikan. Selanjutnya dilihat dari koefisien determinasi diperoleh nilai sebesar 0,021 yang artinya bahwa kontribusi yang diberikan oleh KL,P,CP terhadap KP sebesar 2,1\%, sedangkan sisanya dipengaruhi oleh variabel lain yang tidak diteliti pada penelitian ini.

\section{Pembahasan}

\section{Pengaruh Kualitas Layanan Terhadap Kepuasan Nasabah}

Hasil penelitian ini sejalan dengan penelitian Rusmawati dan Marlindawaty dimana dalam penelitiannya kualitas layanan tidak berpengaruh terhadap kepuasan nasabah (Malindawaty, 2018). Hasil penelitian ini tidak sejalan dengan hasil penelitian Luh Ayu Mulyaningsih dan I Gst Agung Ketut Gede Suasana (Suasana, 2016), Elza Finnora dan Ismail Razak (Finnora, 2017), Muh Ali Maskuri (Maskuri, 2018) dan Sri Rahayu (Rahayu, 2012) karena dalam penelitiannya kualitas layanan berpengaruh terhadap kepuasan nasabah.

Kualitas layanan merupakan suatu kondisi dinamis yang berhubungan dengan produk, jasa, manusia, proses dan lingkungan yang memenuhi atau melebihi harapan (Sopiah, 2013). Kualitas layanan merupakan aspek yang penting dan harus dijaga oleh perusahaan dalam rangka mempertahankan nasabah agar terus menabung terhadap berbagai produk yang ditawarkan. Apabila layanan yang diterima atau yang dirasakan sesuai dengan yang diharapkan maka kualitas pelayanan dipersepsikan baik dan memuaskan. Dalam penelitian ini tidak berpengaruh kualitas layanan terhadap kepuasan nasabah karena kualitas layanan yang diberikan oleh staf Bank BTPN masih kurang kepada nasabah BTPN. Misalnya customer 
Apren Holomoan Hutasoit, Sugianta Ovinus Ginting, Eric

service tidak memberikan merespon keluhan nasabah pada waktu nasabah komplain mengenai masalah aplikasi jenius bermasalah.

\section{Pengaruh Promosi Terhadap Kepuasan Nasabah}

Hasil penelitian ini sejalan dengan penelitian Sri Rahayu dimana dalam penelitiannya promosi tidak berpengaruh secara parsial terhadap kepuasan nasabah (Rahayu, 2012). Hasil penelitian ini tidak sejalan dengan hasil penelitian Muh Ali Maskuri (Maskuri, 2018) dan Rusmawati dan Malindawaty (Malindawaty, 2018) karena dalam penelitiannya promosi berpengaruh terhadap kepuasan nasabah.

Promosi merupakan kegiatan yang ditujukan untuk mempengaruhi nasabah agar mereka dapat menjadi kenal akan produk yang ditawarkan oleh perusahaan kepada mereka dan kemudian mereka menjadi senang lalu menabung produk tersebut (Sunyoto, 2014). Sifat-sifat produk yang agak ditekan dalam hal promosi akan menyebabkan timbulnya kepuasan nasabah yang meningkat, sudah tentu dengan catatan bahwa klaim-klaim tentang produk tidaklah begitu rendah, sehingga akibatnya berupa nasabah memilih produk bank lain. Dalam penelitian ini tidak berpengaruhnya variabel promosi terhadap kepuasan nasabah karena jarangnya penerbitan iklan membuat masyarakat kurang mengetahui manfaat produk dan biaya Bank BTPN untuk promosi masih terbatas. Berbagai masalah yang timbul memperlihatkan bahwa promosi yang dilakukan belum mampu mendukung perusahaan untuk memperkenalkan produk kepada nasabah.

\section{Pengaruh Citra Perusahaan Terhadap Kepuasan Nasabah}

Hasil penelitian ini sejalan dengan hasil penelitian Ulva Septiani Sutrisno, Supri Wahyudi Utomo, Elva Nuraina dimana dalam penelitiannya citra erusahaan tidak berpengaruh secara parsial terhadap kepuasan nasabah (Sutrisno et al, 2017). Hasil penelitian ini tidak sejalan dengan hasil penelitian Luh Ayu Mulyaningsih dan I Gst Agung Ketut Gede Suasana (Suasana, 2016), Elza Finnora dan Ismail Razak (Finnora, 2017), karena dalam penelitiannya citra perusahaan berpengaruh terhadap kepuasan nasabah.

Citra perusahaan adalah kesan, perasaan dan gambaran dari publik terhadap perusahaan, kesan yang sengaja diciptakan dari suatu objek, orang-orang atau organisasi. Citra perusahaan adalah kesan keseluruhan terhadap posisi produk ditinjau dari persaingannya dengan produk lain yang diketahui nasabah apakah produk tersebut dipandang nasabah sebagai produk yang kuat. Sebagian alasan nasabah memilih suatu produk karena nasabah ingin memahami diri sendiri dan untuk mengomunikasikan aspek diri nasabah ke orang lain. Citra perusahaan ini bisa diukur dengan menanyakan atribut apa dari suatu produk yang merupakan pilihan nasabah dalam satu kategori produk yang membedakannya dengan produk lain, mengapa atribut-atribut itu penting dan mengapa alasan itu penting bagi nasabah. Dalam penelitian ini tidak berpengaruhnya variabel citra perusahaan terhadap kepuasan nasabah karena citra perusahaan dari Bank BTPN saat ini masih kurang dikenal oleh masyarakat. Hal ini disebabkan oleh kurang lengkapnya fasilitas yang di tawarkan oleh Bank BTPN. Misalnya jumlah ATM yang masih terlalu sedikit dan mesin ATM untuk setoran tidak ada. Karyawan kurang sigap dalam melayani nasabah dan karyawan kurang ramah dalam menangani nasabah. 
Apren Holomoan Hutasoit, Sugianta Ovinus Ginting, Eric

\section{Pengaruh Kualitas Layanan, Promosi dan Citra Perusahaan Terhadap Kepuasan Nasabah}

Hasil pengujian menunjukkan bahwa variabel kualitas layanan, promosi dan citra perusahaan secara simultan berpengaruh terhadap kepuasan nasabah dengan nilai $\mathrm{F}_{\text {hitung }}$ sebesar 2,676 > $\mathrm{F}_{\text {tabel }}$ sebesar 2,64 dan signifikan 0,048 < 0,05. Dari hasil penelitian ini diperoleh bahwa kualitas layanan, promosi, dan citra perusahaan secara bersama-sama mampu memberikan pengaruh terhadap kepuasan nasabah. Ketiga variabel tersebut jika konsisten dapat dilakukan secara bersamaan akan memberikan dampak positif terhadap nasabah, ketika nasabah melakukan transaksi layanan yang diberikan secara maksimal dan para pegawai cepat dalam memberikan respon hal itu akan mampu meningkatkan kepuasan nasabah, begitu juga kegitan promosi yang dilakukan pihak Bank. Selanjutnya juga ketika Bank tersebut dapat memberikan kesan yang baik kepada nasabah maka nasabah akan menilai Bank tersebut memiliki reputasi yang baik.

\section{Kesimpulan}

Dari hasil penelitian ini diperoleh bahwa variabel kualitas layanan tidak berpengaruh terhadap kepuasan nasabah, promosi tidak berpengaruh terhadap kepuasan nasabah, dan citra perusahaan tidak berpengaruh terhadap kepuasan nasabah. Hasil dari penelitian ini dapat disimpulkan bahwa kontribusi dari variabel kualitas layanan, promosi dan citra perusahan tidak memberikan kontribusi yang signifikan. Namun dalam hasil koefisien determinasi kontribusi dari ketiga variabel independen hanya memberikan kontribusi sebesar 2,1 persen.

\section{Daftar Pustaka}

D. Sunyoto, (2014) Dasar-dasar Manajemen Pemasaran, Yogyakarta:CAPS.

E. Finnora, (2017) "Pengaruh Kualitas Layanan dan Citra Perusahaan Terhadap Kepuasan Nasabah".

E. M. S. d. Sopiah, (2013) Perilaku Konsumen: Pendekatan Praktis Disertai Himpunan Jurnal Penelitian, Yogyakarta: Andi.

F. Tjiptono, (2014) Manajemen Jasa, Yogyakarta: Andi.

Kasmir, (2010) Kewirausahaan, Jakarta : PT Raja Grafindo Persada.

L. A. M. d. I. G. A. K. G. Suasana, (2016) "Pengaruh Kualitas Layanan dan Citra Perusahaan Terhadap Kepuasan Nasabah Pada Bank OCBC NISP di Denpasar”, vol. 5, no. ISSN: 2302-8912, pp. 1-30.

M. A. Maskuri, (2018) "Pengaruh Kualitas Pelayanan dan Promosi Terhadap Kepuasan Nasabah Bank," JURNAL PENGEMBANGAN WIRASWASTA, vol. 20, no. ISSN : 2620-388X.

M. Setiawan, "Efektivitas Iklan IM3 Raja Voucher dan Penggunaan Endorser Terhadap Citra Perusahaan Pada Masyarakat Surabaya".

M. Sumarni, (2012) Manajemen Pemasaran Bank, Yogyakarta: Liberty.

Mulyaningsih, L. A. and Suasana, I. G. A. K. G. (2016) 'Pengaruh Kualitas Layanan Dan Citra Perusahaan Terhadap Kepuasan Nasabah Pada Bank OCBC NISP Di Denpasar', EJurnal Manajemen Universitas Udayana. Udayana University, 5(1).

N. L. d. W. H. Susilo, (2012) Manajemen Pemasaran : Teori dan Aplikasi Dalam Bisnis, Jakarta: Mitra Wacana Media.

P. Kotler, (2013) Manajemen Pemasaran 2, Jakarta: Erlangga. 
R. d. Malindawaty, (2018) "Analisis Kualitas Pelayanan, Harga dan Promosi Terhadap Kepuasan Pelanggan Laundry BJR Batakan Balikpapan," Jurnal Eksekutif, vol. 15.

R. Lupiyoadi, (2013) Manajemen Pemasaran Jasa : Teori dan Praktek, Jakarta: Salemba Empat.

S. Rahayu, (2012) "Pengaruh Promosi, Kualitas Layanan, Citra Merek Terhadap Kepuasan

Wisatawan dan Implikasinya Terhadap Loyalitas Wisatawan Pada Objek Pariwisata di DKI Jakarta," Jurnal Manajemen, vol. XVI, pp. 160-177.

Sugiyono, (2014) Metode Penelitian Bisnis, Bandung: Alfabeta.

S. W. U. E. N. Ulva Septiani Sutrisno, (2017) "Pengaruh Produk WOW dan Citra Perusahaan Teradap Kepuasan Nasabah Pada PT Bank Tabungan Pensiunan Nasional Tbk Cabang Madiun," Forum Ilmiah Pendidikan Akuntansi, vol. 5 No. 1, no. ISSN : 2337-9723, pp. $818-835$.

T. R. R. d. M. H. Aksa, (2011) Manajemen Pemasaran Jasa, Jakarta: Ghalia Indonesia.

T. Suryani, (2017) Manajemen Pemasaran : Strategik Bank di Era Global, Jakarta: Prenadamedia Group.

Wijayanto, K. (2015) 'Pengaruh kualitas pelayanan terhadap kepuasan dan loyalitas nasabah bank', Jurnal Manajemen Dayasaing, 17(1), pp. 38-45. 